\title{
ANALYSIS OF THE INFLUENCE OF CORPORATE SIZE, LEVERAGE , PRICE EARNING RATIO (PER) AND RETURN ON EQUITY (ROE) ON COMPANY VALUE
}

\author{
Tegar Prasetya, Setyo Riyantob \\ Mercu Buana University, Jakarta, Indonesia and \\ Mercu Buana University, Jakarta, Indonesia \\ Email:55119110034.student@mercubuana.ac.id and setyo.riyanto@mercubuana.ac.id
}

\section{ARTICLE INFO}

Date received : 01 August 2020

Revision date : 05 October 2020

Date received : 10 November 2020

\section{Keywords:}

Leverage

Price Earning Rate (PER)

Return on Equity (ROE)

\begin{abstract}
This study aimed to $\mathrm{n}$ use values the company can be determined by many factors, among which the size of the company, leverage, the price earnings ratio (PER) and Return On Equity (ROE) Firm size is considered able to influence the value of the company . the large size of the company shows that the company is developing so that investors will respond positively and the value of the company will increase. The relative market share shows the company's competitiveness is higher than its main competitors. Investors will respond positively so that the value of the company will increase.

Companies that have total assets with large amounts or commonly referred to as large companies will get more attention from investors, creditors and other users of financial information compared to small companies. If the company has a large total assets, the management will be more flexible in using existing assets in the company. This ease in controlling assets will increase the value of the company. In the face of economic turmoil, usually a more sturdy company stands are large, although it does not rule out bankruptcy, so investors tend to like large-sized companies rather than small-sized companies.
\end{abstract}

\section{INTRODUCTION}

The establishment of a company must have a clear purpose. There are short term goals and also long term goals. In the short term the company aims to achieve maximum profits by using existing resources, while in the long run the company's goal is to maximize the welfare of shareholders by increasing the value of the company or wealth for shareholders. Company value is a proxy that describes the prosperity of shareholders (Agus Sartono, 2002).

The value of shareholders will increase if the value of the company increases marked by a high rate of return on investment to shareholders. The value of the company will increase if the share price increases and vice versa the value of the company will decrease if the share price decreases. Wealth $p$ emegang stock and in a re pre sentasikan by the market price of the shares is a reflection of the investment decision. According to (Soliha, 2002), high company value is the desire of company owners, because with high company value, it shows that shareholder wealth is also high. $U$ ntuk achieve the objectives of the company, man ajer make investment decisions that resulted in a positive net present value.

According to (Sartono Sartono, 2008) the value of a company is defined as the price that potential investors must be willing to pay if a company is to be sold. Company value can reflect the value of assets owned by the company such as securities. Stock is one of the securities issued by the company, the high and low of shares is much influenced by the issuer. One of the factors that influence stock prices is the ability of companies to pay dividends.

Company value for companies that have gone public, can be determined by the mechanism of supply and demand on the exchange, which is reflected in the listing price (Karnadi, 1993). 
With the good value of the company then the company would be viewed favorably by prospective investors, and vice versa if the value of the bad company it will be in the negative light by the prospective investor. For creditors the value of the company is related to company liquidity, that is, the company is considered capable of whether or not the loan can be returned by the creditor. If the value of the company is not implied, the investor will assess the company with a low value.

Company value can be determined by many factors, including company size, leverage, price earning ratio (PER) and Return On Equity (ROE). The size of the company is considered able to influence the value of the company. According to (Sujoko, Safitri, \& Anindita, 2007) the size of a large company shows that the company is developing so that investors will respond positively and the value of the company will increase. The relative market share shows the company's competitiveness is higher than its main competitors. Investors will respond positively so that the value of the company will increase.

The company that has total assets with large quantities or so-called d e ngan large enterprises will more get the attention of investors, creditors and other users of financial information compared with small companies. If peruusahaan has total assets were great then the management will be freer use of existing assets diperusahaa $n$ such. Ease dal a $m$ pulled ndalikan these assets that will enhance shareholder value. In the face of economic shocks, usually a more robust stand adal a $\mathrm{h}$ large-sized company though did not rule endured bankruptcy, so investors tend to favor large-sized enterprise $d a$ ri on small-sized enterprise.

Research conducted by (Prasetyorini, 2013) shows that company size influences firm value. While the research conducted by (Ayu \& Ary, 2013) , company size has no effect on firm value. From the results of research conducted showed different results .

Another factor that influences the company's value is leverage. Leverage ratios can be seen through several ratios including Dept to Asset Ratio, Longre Debt to Asset Ratio, Equity to Asset Ratio, and Debt to Equity Ratio. From these various ratios, this study uses Debt to Equity Ratio (DER) to measure the company's capital structure. Debt to Equity Ratio ( DER ) is a ratio used to describe how the ability of a company to pay off debts owned by the company. Total debt consists of short-term debt and long-term debt. Debt to Equity Ratio ( DER ) can be measured by comparing the liabilities with total equity. With the debt owned by the company, the company is expected to be able to fund and manage its assets to make a profit so that the company's value will increase. The size of the Debt to Equity Ratio (DER) produced by the company $\mathbf{B}$. can affect the value of the company. Debt to Equity Ratio (DER) increasing m enunjukkan risk investment growing too and vice versa if the Debt to Equity Ratio (DER) the less it will show a small investment risk. Debt to Equity Ratio (DER) with a number below 1.00 indicates that the company has a debt that is smaller than the equity it has.

From the results of research conducted by $B$ (hekti, 2013) shows that leverage has no effect on firm value. While the results of research conducted by Faradila, et al (2017) show that leverage has a negative effect on firm value.

Another factor influencing company value is the price earning ratio (PER). This ratio shows how much investors assess the price of shares against multiples of earnings (Jogiyanto, 2010: 146). For investors, the higher the price earning ratio (PER), the expected profit growth will also increase. By looking at Price Earning (PER) can show stock prices that reflect information to potential investors. So that investors will be more confident in making decisions to invest.

The next factor influencing company value is ROE. Return On Equity (ROE) is a comparison between net profit after tax with total own capital, retained earnings, and other reserves owned by the company according to Hutami (2012: 2). Return On Equity Ratio (ROE) shows how far the company can manage its own capital efficiently. This ratio can be used by investors as a tool to consider in decision making. The higher the Return On Equity (ROE) the better the company and the higher the rate of return to shareholders. a high level of Return On Equity Ratio (ROE) will attract investors.

Based on the background described above, this researcher takes the title "Effect of Company Size, Leverage, Price Earning Ratio and Return On Equity (ROE) Against Company Value (Case Study in Manufacturing Companies in Consumption Industry Sector Manufacturing Listed on the Indonesia Stock Exchange in 2014 -2016).

\section{METODE}

\section{A. Types of research}

This type of research used by researchers is a comparative casual study that aims to investigate the possibility of a causal relationship, but not by way of experimentation but is carried out by observing data from factors that are suspected to be causes for comparison.

The dependent variable in this study is the value of the company at manufacturing consumer goods industry sector listed on stock exchanges Indonesia in 2014 - 2016, while the independent variable in this study is the size of the company, $L$ everage , Price Earning $R$ atio (PER) and Return On Equity (ROE). The approach used in this study is a quantitative approach because the data used are numbers.

\section{Population and Sample}

\section{Research Population}


Population is a collection of all elements that are the center of research objects (Supomo \& Indrianto, 2012). The population in this study is manufacturing companies in the consumer goods industry sector which are listed on the Indonesia Stock Exchange (IDX). This research uses the 2014 to 2016 research period.

\section{Research sample}

This research was taken using the purposing sampling method. Pupposing sampling is a return of samples carried out in accordance with established research objectives (Now: 200) criteria for sampling data include:

a. Company manufacturing consumer goods industry sector listed in Indonesia Stock Exchange in 2014-2016.

b. Data financial statements during the study period ie 2014.2015 and 2016 .

c. Companies that have the data needed in this study.

\section{Data and Data Sources}

The data used in this research is secondary data. Secondary data is data obtained by researchers indirectly through intermediary media. Data sources used in this study were obtained through searches from the Indonesia Capital Market Directory (ICDM), the website www.idx.co.id and from internet media and websites.

\section{Method of collecting data}

In research, data collection techniques are an important factor for the success of research. The usual data used in this research is the method of data collection that is the method of observation obtained from documentation based on financial statements that have been published by the IDX through ICDM and Literature Studies, which is a way in which to obtain data using reading and study books relating to the problems discussed in the scope of this research.

\section{Operational Definition and Variable Measurement \\ 1. Dependent Variable (Y) \\ The dependent variable is the} variable that is explained or influenced by the independent variable (Supomo and Indiarto: 1999). The dependent variable in this company is the value of the company. The value of a company can be measured by Tobin's $Q$. This ratio is a valuable concept because it shows the current financial market estimation of the return on every dollar of investment in the future. According to (Bhekti, 2013) in (Smithers \&
Wright, 2007) Tobin's $Q$ is calculated by the ratio of the market value of the company's stock plus debt and then compares it to the company's total assets. The formula is as follows:

Tobin's $\mathrm{Q}=\frac{M V E+D e b t}{T A}$

Tobin's $Q<1$ analysis then shows that the book value of the company's assets is greater than the market value of the company, so the company will be an attractive acquisition target either to be combined with other companies or to be liquidated because the value of the shares is valued low (undervalued). Conversely, if the value of Tobin's $Q>1$ indicates that the company's market value is higher than the book value of its assets, thus indicating that the company has high growth potential so that the company's value is more than just the value of its assets (overvalued).

\section{Independent Variable (x)}

Independent variables are variables that explain or influence other variables (Supomo \& Indianto, 1999). The independent variables in this study are:

a. Company Size

According to (Ferry \& Jones (in Sujianto, 2001) the size of the company describes the size of a company as indicated by total assets, total sales, average total sales and average total assets. So, the size of the company is the size or size of the assets owned by the company. Mathematically can be formulated as follows:

\section{Size : total assets}

a. Leverage

Leverage or solvency of a company shows the company's ability to fulfill all financial obligations if the company is liquidated at a time. Leverage in this study is calculated using the Debt to Equity Ratio (DER) ratio used to assess debt with equity. This ratio is sought by comparing all debt, including current debt and all equity (Kasmir, 2014). Mathematically Debt to Equity Ratio (DER) can be formulated as follows:

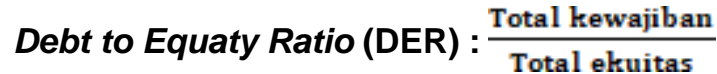

\section{b. Price Earning Ratio (PER)}

The cheaper the price of shares purchased indicates the smaller the value of the Price Earning Ratio (PER) 
so that the better the performance per share in generating company profits. So that many investors will be interested in buying these shares because the performance per share is getting better. According to (Tandelilin, 2010) the formula for calculating the Price Earning Ratio (PER) of a stock is to divide the stock price by earnings per share. mathematically the formula to calculate Price Earning Ratio (PER) is as follows:

$$
\text { PER }=\frac{\text { Harga Saham }}{\text { Earning per lembar saham }}
$$

c. ROE

According to Syafri (2008) Return On Equity (ROE) is a comparison between net income after tax and total equity. Return On Equity (ROE) is a measure of income available to company owners (be they ordinary shareholders or preferred stockholders) for the capital they invest in a company. By mathematically formulated as follows:

Return On Equity (ROE) $=\frac{\text { laba bersih setelah pajak }}{\text { Total Ekwitas }}$

Table 1

Summary of Operational Definition and Variable Measurement

\begin{tabular}{|c|c|c|}
\hline $\begin{array}{l}\text { Research } \\
\text { variable }\end{array}$ & $\begin{array}{l}\text { Definition of Variable } \\
\text { Operations }\end{array}$ & Scale \\
\hline $\begin{array}{l}\text { The value of } \\
\text { the company } \\
\text { (Tobin's Q) }\end{array}$ & $\begin{array}{l}\text { MVE (number of } \\
\text { shares outstanding } \\
\text { times the closing } \\
\text { price) plus the total } \\
\text { value of the } \\
\text { company's liabilities } \\
\text { divided by the total } \\
\text { assets of the } \\
\text { company }\end{array}$ & Ratio \\
\hline $\begin{array}{l}\text { Leverage } \\
\text { (DER) }\end{array}$ & $\begin{array}{l}\text { Total liabilities } \\
\text { divided by total equity }\end{array}$ & Ratio \\
\hline $\begin{array}{l}\text { Company Size } \\
\text { (SIZE) }\end{array}$ & Total assets & Interval \\
\hline $\begin{array}{l}\text { Price Earning } \\
\text { Ratio } \\
\text { (PER) }\end{array}$ & $\begin{array}{l}\text { The share price is } \\
\text { divided by earning } \\
\text { per share }\end{array}$ & Ratio \\
\hline $\begin{array}{l}\text { Return } \\
\text { Equaity } \\
\text { (ROE) }\end{array}$ & $\begin{array}{l}\text { Net income after tax } \\
\text { divided by total equity }\end{array}$ & Ratio \\
\hline
\end{tabular}

\section{E. Data Analysis Method}

\section{Descriptive statistics}

Descriptive Statistics is a statistical tool that functions to describe or provide an overview of the object under study through sample data or population as they are, without analyzing and making general conclusions from the data (Sugiyono, 2004). Descriptive statistics are used to describe data that is seen from the mean, median, standard deviation, minimum value, and maximum value. This test is done to make it easier to understand the variables used in research.

\section{Asumsi Classik}

This classic assumption test aims to find out and test the feasibility of the regression model used in this study. This test is also intended to ensure that in the regression model used there is no multicollinearity and heteroscedasticity and to ensure that the data generated are normally distributed (Ghozali, 2011).

a. Normality test

The normality test aims to test whether in the regression model the independent variable and the dependent variable or both are normally distributed or not. A good regression model is having normal or near normal data distribution. To detect normality of data can be tested with kolmogorof-Smirnof . The Kolmogrof-Smirnof test uses SPSS assistance to find out whether the data is normally distributed or not seen from Asymph. Sig (2- tailed).

Research data are said to be normal or meet the normality test if the Asymph Sig (2-tailed) residual variable is above 0.05 or $5 \%$. Conversely, if the Asimph Sig (2- tailed) value of the residual variable is below 0.05 or $5 \%$, then the data is not normally distributed or does not meet the normality test.

b. Multicollinearity Test

Multicoloniarity The purpose of the test is to test whether the regression model has a correlation between variables occurs bebas.Multikolonieritas ji ka linear relationship between independent who engage in the model. If there is a high multicollinearity symptom , then the standard error of the regression coefficient will be even greater, consequently the internal evidence for the parameter estimation will be wider. To find out whether or not there is a problem with this test is done by looking at the value of Tolerance and VIF (Variance Inflation Factor). The recommended value to indicate the absence of multicollinearity problems is the Tolerence value must be> 0.10 and VIF $<10$.

c. A test of utocorrelation 
Autocorrelation test occurs when there is a deviation from observation by another deviation. There are several ways to detect the presence of aoutocorrelation, one of them is the dusbin-waton (DW) test. The dusbinwatson decision making criteria are as follows:

1. If the $D W$ value is exactly equal to 2 then perfect autocorrelation does not occur

2. If the DW value is between 1.5 to 2.5 then the data does not experience autocorrelation

3. If the DW value $=0$ to 1.5 then it has a positive auotocorrelation

4. If $\mathrm{DW}>2.5$ to 4 then it has negative autocorrelation.

d. Heteroskesdatisitas test

Heteroskesdatisistas test aims to determine whether the variance from one observation to another observation is different or fixed. If the variance from the same data residual is called homokedastisity and if it is different is called heteroscedaticity. To detect heteroscedasticity in regression, you can use glacier test. Glejser test is transforming the residual value into absolute and regressing it with the independent variables of the model. If the significance value for the independent variable> 0.05 then can is stored $p$ ulkan there are no issues Heterskedastisitas.

\section{Regression Analysis}

Regression analysis is used to determine the effect of the independent variables in influencing the independent variables together or partially. The regression equation in this study is :

$$
\mathbf{Y}=\mathbf{a}+\beta \mathbf{X} 1+\beta \mathrm{X} 2+\beta \mathrm{X} 3+\beta \mathrm{X} 4+\mathrm{e}
$$

Information:

$$
\begin{array}{ll}
\mathrm{Y} & =\text { Company Value } \\
\mathrm{a} & =\text { constant } \\
\beta 1, \beta 2, \beta 3, \beta 4 & =\quad \text { Regression } \\
\text { Coefficient } & \\
\mathrm{X} 1 & =\text { Company Size } \\
\mathrm{X} 2 & =\text { Leverage } \\
\mathrm{X} 3 & =\text { Price Earning } \\
\text { Ratio } & \\
\mathrm{X} 4 & =\mathrm{ROE} \\
\mathrm{e} & =\text { Residual variable }
\end{array}
$$

\section{Hypothesis test}
a. Partial Test (t-test statistic)
$T$ test aims to determine
individually the effect of one

independent variable on the dependent variable. If the significance value generated by the $t$ test is $P<0.05$, it can be concluded that partially the independent variable has a significant effect on the dependent variable. Partial test is used to test the effect of the independent variable on the independent variable with the provisions that if the significance level is more than $5 \%$, it can be concluded that $\mathrm{H} 0$ is accepted and $\mathrm{Ha}$ is rejected, whereas if the significance level is less than $5 \%$ then it can be concluded that Ho is rejected and $\mathrm{Ha}$ is accepted.

b. Simultaneous significance test (Statistical test $\mathrm{F}$ )

The $F$ test aims to determine whether all the variables included in the regression model have a simultaneous effect on the dependent variable or not. If the significance is generated by the $F$ test, $\mathrm{P}<0.05$, it can be concluded that all the independent variables simultaneously have a significant effect on the variable. Another way that can be used is to compare the statistical $F$ with the $F$ table. If $F$ statistic> $F$ table, it can be concluded that partially the independent variable has a significant effect on the dependent variable.

c. The coefficient of determination The coefficient of determination (R2) measures how far the model's ability to explain the variation of the dependent variable (Ghozali \& Chariri, 2007). The greater R2 (close to 1), the better the results for the regression model and the closer to 0 , the overall independent variable can not explain the dependent variable (Sulaiman, 2004). A small R2 value means that the ability of the variables to explain the dependent variable is very limited. A value close to 1 means that the independent variables provide all the information needed to predict variations in the dependent variable (Ghozali, 2011). 


\section{RESULTS AND DISCUSSION}

\section{A. Research result}

1. Descriptive Data

In this study, researchers chose manufacturing companies in the consumer goods industry sector which were listed on the Indonesia Stock Exchange in 2014-2016 as research objects. Industrial companies in the consumer goods sector are included in manufacturing companies because these companies convert raw materials into finished goods through mechanical processes. This sector is still the main choice for investors in investing their funds. This is because shares of companies in the consumer goods industry sector still offer upward potential. The consumer goods industry sector includes various industrial sub-sectors such as the food and beverage industry, cigarettes, pharmaceuticals, cosmetics, household goods, and household appliances.

The data used in this study are secondary data obtained from the Indonesia Capital Market Directory (ICDM) and the Indonesia Stock Exchange Website. In this study the population of 40 manufacturing companies in the consumer goods industry sector. Sampling in this study was carried out using a surposive sampling technique that is sampling based on certain criteria, the criteria in sampling are as follows :

a. Manufacturing companies in the consumer goods industry sector were listed on the Indonesia Stock Exchange in 2014-2016.

b. Financial statement data for the study period, 2014,2015 and 2016.

c. Companies that have the data needed in this study

Based on the above criteria there are 19 samples of manufacturing companies in the consumer goods industry sector that have data in accordance with what is needed by this study.

Tabel 2 List of sample manufacturing companies

\begin{tabular}{|c|c|c|}
\hline NO & $\begin{array}{c}\text { Company } \\
\text { Code }\end{array}$ & Company name \\
\hline 1 & AISA & $\begin{array}{l}\text { PT Tiga Pilar Sejahtera Food } \\
\text { Tbk }\end{array}$ \\
\hline 2 & MLBI & $\begin{array}{l}\text { PT Multi Bintang Indonesia } \\
\text { Tbk }\end{array}$ \\
\hline 3 & ROTI & $\begin{array}{l}\text { PT Nippon Indosari } \\
\text { Corporindo Tbk }\end{array}$ \\
\hline 4 & SKBM & PT Sekar Bumi Tbk \\
\hline 5 & STTP & PT Siantar Top Tbk \\
\hline 6 & GGRM & PT Gudang Garam Tbk \\
\hline 7 & WIIM & PT Wismilak Inti Makmur Tbk \\
\hline 8 & DVLA & $\begin{array}{l}\text { PT Darya Varia Laboratori } \\
\text { Tbk }\end{array}$ \\
\hline 9 & KAEF & Kimia Farma Tbk \\
\hline 10 & KLBF & Kalbe Farma Tbk \\
\hline 11 & PYFA & Pyridam Farma Tbk \\
\hline
\end{tabular}

\begin{tabular}{|c|c|c|c|c|c|}
\hline 12 & TSPC & \multirow{2}{*}{\multicolumn{4}{|c|}{$\begin{array}{l}\text { Tempo Scan Pasific Tbk } \\
\text { PT Akasha Wira International } \\
\text { Tbk }\end{array}$}} \\
\hline 13 & ADES & & & & \\
\hline 14 & UNVR & \multicolumn{4}{|c|}{ Unilever Indonesia Tbk } \\
\hline 15 & CINT & \multicolumn{4}{|c|}{$\begin{array}{l}\text { PT Chitose Internatiomnal } \\
\text { Tbk }\end{array}$} \\
\hline 16 & LMPI & \multicolumn{4}{|c|}{$\begin{array}{l}\text { Langgeng Makmur Industri } \\
\text { Tbk }\end{array}$} \\
\hline 17 & ICBP & \multicolumn{4}{|c|}{$\begin{array}{l}\text { PT Indofood CBP Sukses } \\
\text { Makmur Tbk }\end{array}$} \\
\hline \multicolumn{6}{|c|}{ Descriptive Statistics } \\
\hline & $\mathrm{N}$ & $\begin{array}{l}\text { Mini } \\
\text { mum }\end{array}$ & $\begin{array}{l}\text { Maxi } \\
\text { mum }\end{array}$ & Mean & $\begin{array}{c}\text { Std. } \\
\text { Deviation }\end{array}$ \\
\hline LNTobinsQ & 57 &,- 45 & 3,44 & ,8491 & ,86479 \\
\hline LNSIZE & 56 & $\begin{array}{c}25,8 \\
0\end{array}$ & $\begin{array}{c}31,7 \\
8\end{array}$ & $\begin{array}{c}28,677 \\
3\end{array}$ & 1,48540 \\
\hline $\begin{array}{l}\text { LNDER } \\
\text { LNPER }\end{array}$ & $\begin{array}{l}57 \\
57\end{array}$ & $\begin{array}{c}-1,54 \\
, 62\end{array}$ & $\begin{array}{l}1,11 \\
4,63\end{array}$ & $\begin{array}{l}-, 2950 \\
2,9813\end{array}$ & $\begin{array}{l}, 71467 \\
, 70625\end{array}$ \\
\hline LNROE & 57 & $-5,52$ &, 50 & 1,9395 & 1,11891 \\
\hline $\begin{array}{l}\text { Valid N } \\
\text { (listwise) }\end{array}$ & 56 & & & & \\
\hline 18 & ULTJ & \multirow{2}{*}{\multicolumn{4}{|c|}{$\begin{array}{l}\text { PT Ultrajaya Milk Industry } \\
\text { and Trading Company Tbk } \\
\text { PT Mayora Indah Tbk }\end{array}$}} \\
\hline 19 & MYOR & & & & \\
\hline
\end{tabular}

2. Descriptive statistics

Descriptive Statistics is a statistical tool that serves to describe or provide an overview of the object under study through sample data and population as they are, without analyzing and making generally accepted conclusions from the data (Sugiyono, 2004). Descriptive statistics are used to describe data that is seen from the mean, median, standard deviation, minimum value, and maximum value. This test is done to make it easier to understand the variables used in research.

Tabel 3 Descriptive statistical test results

a. The value of the company

The value of the company is shown by the TobinsQ proxy. Based on the descriptive statistical test results in table 4.1 it can be seen that the minimum value of TobinsQ is -0.45 and the maximum value is 3.44 . This shows that the value of Tobins $Q$ in this study sample ranged from -0.45 to 3.344 with an average (mean) of 0.8491 at a standard deviation of 0.86479 .

b. Company size

The size of the company is indicated by the SIZE proxy. Based on the descriptive statistical test results in table 4.2 it can be seen that the minimum value of SIZE is 25.80 and the maximum value is 31.78 . This shows that the magnitude of the SIZE value in this study sample ranged from 25.80 to 31.78 with an average (mean) of 28.6773 at a standard deviation of 1.48540 . 
c. Leverage

Leverage is shown by the Debt to Equity Ratio (DER) proxy. Based on the results of testing descriptive statistics on

Return On Equity (ROE) is indicated by the ROE proxy. Based on the results of descriptive statistics testing in table 4.2 it can be seen that the minimum value of table 4.2 can be seen that the minimum value of DER is -1.54 and the maximum value is 1.11. This shows that the magnitude of the DER value in this study sample ranged from -1.54 to 1.11 with an average (mean) of -0.2950 at a standard deviation of 0.71467 .

d. Price Earning Ratio (PER)

Price Earning Ratio (PER) is indicated by the proxy PER. Based on the descriptive statistical test results in table 4.2 it can be seen that the minimum PER value is 0.62 and the maximum value is 4.63. This shows that the magnitude of the PER value in this study sample ranged from 0.62 to 4.63 with an average (mean) of 2.9813 on a standard deviation of 0.70625 .

e. Return On Equity (ROE)

ROE of -5.50 and a maximum value of 0.50 . This shows that the magnitude of the ROE value in this study sample ranged from -5.52 to 0.50 with an average (mean) of -1.9395 at a standard deviation of 1.11891

3. Classic assumption test

a. Normality test

The normality test aims to test

One-Sample Kolmogorov-Smirnov Test

\begin{tabular}{ccc}
\hline & & $\begin{array}{c}\text { Unstandardi } \\
\text { zed } \\
\text { Residual }\end{array}$ \\
\hline Normal & & 56 \\
\hline Parameters & & Mean \\
Most Extreme & Std. Deviation &, 56077113 \\
Differences & Absolute &, 145 \\
& Positive &, 145 \\
\hline \multicolumn{2}{c}{ Kolmogorov-Smirnov Z } &,- 133 \\
\hline \multicolumn{2}{c}{ Asymp. Sig. (2-tailed) } & 1,088 \\
\hline
\end{tabular}

a. Test distribution is Normal.

whether in the regression model the independent variable and the dependent variable or both are normally distributed or not. A good regression model is having normal or near normal data distribution. To detect normality of data can be tested with kolmogorof-Smirnof. The KolmogrofSmirnof test uses SPSS assistance to find out whether the data is normally distributed or not seen from Asymph. Sig (2- tailed).
Research data are said to be normal or meet the normality test if the Asymph Sig (2- tailed) residual variable is above 0.05 or $5 \%$. Conversely, if the Asimph Sig (2- tailed) value of the residual variable is below 0.05 or $5 \%$, then the data is not normally distributed or does not meet the normality test.

\section{Tabel 4 Normality Test Results}

Based on the results of the normality test using the KolmogrovSmirnov test in table 4.3 shows the Asymp.Sig value (2 $t$ ailed) of 0.188 whose value is greater than 0.05 . this means that overall data is normally

\section{Coefficients}

\begin{tabular}{|c|c|c|c|c|c|c|c|}
\hline \multirow[t]{2}{*}{ Model } & \multicolumn{2}{|c|}{$\begin{array}{c}\text { Unstandardized } \\
\text { Coefficients }\end{array}$} & $\begin{array}{l}\text { Standa } \\
\text { rdized }\end{array}$ & \multirow[t]{2}{*}{$\mathrm{T}$} & \multirow[t]{2}{*}{ Sig. } & \multicolumn{2}{|c|}{$\begin{array}{l}\text { Collinearity } \\
\text { Statistics }\end{array}$} \\
\hline & B & $\begin{array}{l}\text { Std. } \\
\text { Error }\end{array}$ & Beta & & & $\begin{array}{c}\text { Tolera } \\
\text { nce }\end{array}$ & VIF \\
\hline $\begin{array}{l}\text { (Constan } \\
\text { t) }\end{array}$ & $-1,054$ & 1,869 & &,- 564 & ,575 & & \\
\hline LNSIZE & ,065 & ,062 & ,110 & 1,049 & 299 & ,737 & 1,356 \\
\hline LNDER &,- 062 & ,116 &,- 051 &,- 531 & ,598 & ,882 & 1,133 \\
\hline LNPER & ,340 & 113 & ,277 & 3,009 & ,004 & ,955 & 1,047 \\
\hline LNROE & 506 & .084 & 655 & 6.047 & 000 & 693 & 1.443 \\
\hline
\end{tabular}

a. Dependent Variable: LNTobinsQ distributed.

b. Multicollinearity Test

Multicoloniarity The purpose of the test is to test whether the regression model has a correlation between variables occurs bebas. Multikolonieritas ji ka linear relationship between independent who engage in the model. If there is a high multicollinearity symptom, then the standard error of the regression coefficient will be even greater, consequently the internal evidence for the parameter estimation will be wider. To find out whether or not there is a problem with this test is done by looking at the value of Tolerance and VIF (Variance Inflation Factor). The recommended value to indicate the absence of multicollinearity problems is the value of Tence rence must be $>0.10$ and $\mathrm{VIF}<10$.

\section{Tabel 5 Multicollinearity Test Results}

Based on the test results Multicolinearity, five independent variables are the size of the company, L everage, Price Earning Ratio (PER), and Return On Equity (ROE) tolerance values above 0.1 and VIF under 10. It can be concluded that 
tida $k$ there are symptoms of multicollinearity.

c. Autocorrelation Test

Autocorrelation test occurs when there is a deviation from observation by another deviation. There are several ways to detect the presence of aoutocorrelation, one of them is the dusbin-waton (DW) test. The dusbin-watson decision making criteria are as follows:

1. If the DW value is exactly equal to 2 then perfect autocorrelation does not occur.

2. If the DW value is between 1.5 to 2.5 then the data does not experience autocorrelation.

3. If the DW value $=0$ to 1.5 then it has a positive auotocorrelation.

4. If $\mathrm{DW}>2.5$ to 4 then it has negative autocorrelation.

Tabel 6 Autocorrelation Test Results

Model Summary

\begin{tabular}{cccccc}
\hline Model & $\mathrm{R}$ & $\mathrm{R}$ & Adjusted \\
Square & R Square & $\begin{array}{c}\text { Std. Error of } \\
\text { the Estimate }\end{array}$ & $\begin{array}{c}\text { Durbin- } \\
\text { Watson }\end{array}$ \\
\hline 1 &, $765^{\mathrm{a}}$ &, 586 &, 553 &, 58235 & 1,970 \\
\hline
\end{tabular}

a. Predictors: (Constant), LNROE, LNPER, LNDER, LNSIZE

b. Dependent Variable: LNTobinsQ

Based on the results of autocorrelation obtained Durbin-Watson value of 2.2391. This value is compared

\section{Coefficients $^{\mathrm{a}}$}

\begin{tabular}{|c|c|c|c|c|c|c|}
\hline \multirow{2}{*}{\multicolumn{2}{|c|}{ Model }} & \multicolumn{2}{|c|}{$\begin{array}{l}\text { Unstandardized } \\
\text { Coefficients }\end{array}$} & $\begin{array}{l}\text { Standard } \\
\text { ized }\end{array}$ & \multirow[t]{2}{*}{$\mathrm{T}$} & \multirow[t]{2}{*}{ Sig. } \\
\hline & & B & $\begin{array}{l}\text { Std. } \\
\text { Error }\end{array}$ & Beta & & \\
\hline & (Constant) &,- 384 & 1,341 & &,- 286 & ,776 \\
\hline & LNSIZE & ,037 &, 044 & ,127 & ,838 & ,406 \\
\hline \multirow[t]{3}{*}{1} & LNDER &,- 001 & ,083 &,- 002 &,- 013 & ,990 \\
\hline & LNPER &,- 036 & ,081 &,- 059 &,- 447 & ,657 \\
\hline & LNROE & 111 & .060 & 289 & 1.853 & .070 \\
\hline
\end{tabular}

a. Dependent Variable: ABRES

with the Durbin-Watson $(k, n)$ table value where $\mathrm{k}$ shows the number of independent variables namely 4 variables and $n$ is the number of samples of 19 samples. Then the value of du table shows 1.8482 and the value of $\mathrm{dl}$ shows 0.8588 , so that $1.8482<1.970<2.1518$, these results indicate that this study did not experience autocorrelation d. Heteroskesdatisitas

Heteroskesdatisistas test aims to determine whether the variance from one observation to another observation is different or remains constant. If the variance from the same data residual is called homokedastisity and if it is different is called heteroscedaticity. To detect heteroscedasticity in regression, you can use glacier test. Glejser test is transforming the residual value into absolute and regressing it with the independent variables of the model. If the significance value for the independent variable> 0.05 , it can be concluded that

\begin{tabular}{|c|c|c|c|c|c|c|c|}
\hline \multicolumn{8}{|c|}{ Coefficients $^{a}$} \\
\hline \multirow[t]{2}{*}{ Model } & \multicolumn{2}{|c|}{$\begin{array}{l}\text { Unstandardized } \\
\text { Coefficients }\end{array}$} & \multirow{2}{*}{$\begin{array}{l}\text { Standa } \\
\text { rdized } \\
\text { Coeffic } \\
\text { ients } \\
\text { Beta }\end{array}$} & \multirow[t]{2}{*}{$\mathrm{T}$} & \multirow[t]{2}{*}{ Sig. } & \multicolumn{2}{|c|}{$\begin{array}{l}\text { Collinearity } \\
\text { Statistics }\end{array}$} \\
\hline & $B$ & $\begin{array}{l}\text { Std. } \\
\text { Error }\end{array}$ & & & & $\begin{array}{l}\text { Toler } \\
\text { ance } \\
\end{array}$ & VIF \\
\hline (Constant) & $-1,054$ & 1,869 & &,- 564 &, 575 & & \\
\hline LNSIZE & ,065 & ,062 & , 110 & 1,049 & 299 & ,737 & 1,356 \\
\hline 1 LNDER &,- 062 & ,116 &,- 051 &,- 531 & ,598 & ,882 & 1,133 \\
\hline LNPER & ,340 & ,113 & 277 & 3,009 & ,004 & ,955 & 1,047 \\
\hline LNROE & ,506 & ,084 & ,655 & 6,047 & ,000 & ,693 & 1,443 \\
\hline
\end{tabular}

a. Dependent Variable: LNTobinsQ

there is no Heterkedastisitas problem

\section{Tabel 7 Heteroskesdatisitas Test Results}

Based on table 7

Heteroskesdatisitas test results indicate that there are no independent variables that are statistically significant influence the dependent variable absolute residual value. This result is seen from the probability of significance above the 5\% confidence level. So it can be concluded that the regression model does not contain heteroskesdatisitas..

4. Regression Analysis

Regression analysis is used to determine the effect of the independent variables in influencing the independent variables together or partially. Regression analysis in this study was used to determine the effect of company size, Leverage, Price Earning Ratio (PER), and Return On Equity $(\mathrm{ROE})$ on firm value in manufacturing companies in the consumer goods industry sector in 2014-2016.

Tabel 8 Regression Test Results

From table 8 the following regression equation can be drawn:

TobinsQ :

$-1,054+0,065$ SIZE

0,062DER+0,340PER+0,506ROE+e 
Keterangan:

Tobins'Q

$\beta$

SIZE

DER

PER

ROE

: Regression Coefficient

: Company Size

: Leverage

: Price Earning Ratio

: Retun On Equity

5. Hypothesis test

a. Partial Test (t Test Statistics)

$T$ test aims to determine individually the effect of one independent variable on the dependent variable. If the significance value generated by the $t$ test $P<0.05$, it can be concluded that partially the independent variable has a significant effect on the dependent variable. Partial test is used to test the effect of the independent variable on the independent variable with the provisions that if the significance level is more than $5 \%$ then it can be concluded that $\mathrm{Ho}$ is accepted and $\mathrm{Ha}$ is rejected, whereas if the significance level is less than $5 \%$ then it can be concluded that $\mathrm{Ho}$ is rejected and $\mathrm{Ha}$ is accepted.

Based on t test in Table 4.7 in at axles, it can be seen that the size of the company has koefisisen regression value with a positive sign of 0.065 with a significance level of 0.299. The significance results indicate that the level of significance of firm size variables is greater than $\alpha=0.05$, it can be concluded that company size has a positive and not significant effect on firm value so hypothesis $1(\mathrm{H} 1)$ which states that company size has a positive and significant effect on firm value rejected.

Leverage is proxied by Debt Earning Ratio (DER) has a regression coefficient with a negative sign of 0.62 with a significance level of 0.598 . The significance results indicate that the level of significance of the Leverage variable is greater than $\alpha=0.05$, it can be concluded that Leverage has a negative and not significant effect on firm value so that hypothesis $2(\mathrm{H} 2)$ which states that Leverage has a positive and significant effect on firm value is rejected.

Price Earning Ratio (PER) has a regression coefficient with a positive sign of 0.340 with a significance level of 0.004 . The significance results show that the significance level of Price Earning Ratio (PER) is smaller than $\alpha=0.05$, so it can be concluded that Price Earning Ratio (PER) has a positive and significant effect on the value of the company so that hypothesis $3(\mathrm{H} 3)$ suggests that Price ANOVA $^{a}$

\begin{tabular}{lrrrrr}
\hline Model & $\begin{array}{c}\text { Sum of } \\
\text { Squares }\end{array}$ & Df & $\begin{array}{c}\text { Mean } \\
\text { Square }\end{array}$ & F & Sig \\
\hline Regressi & 24,450 & 4 & 6,113 & 18,0 &, 00 \\
1 on & 17,296 & 51 &, 339 & & 0 \\
Residual & 17,24 & & \\
Total & 41,746 & 55 & & & \\
\hline
\end{tabular}

a. Dependent Variable: LNTobinsQ

b. Predictors: (Constant), LNROE, LNPER,

LNDER, LNSIZE

Earning Ratio (PER) has a positive and significant effect on the company's value received.

Return On Equity (ROE) has a regression coefficient with a positive sign of 0.506 and a significance level of 0.000 . The significance results indicate that the significance level of the Return On Equity (ROE) variable is small than $\alpha=0.05$, it can be concluded that Return On Equity (ROE) has a positive and significant effect on the firm's value so that hypothesis 4 (H4) states that Return On Equity (ROE) has a positive and significant effect on the value of the company received.

b. Simultaneous significance test (F statistical test)

The $F$ test aims to determine whether all the variables included in the regression model have a simultaneous effect on the dependent variable or not. If the significance is generated by the $F$ test, $P<0.05$, it can be concluded that all the independent variables simultaneously have a significant effect on the variable.

\section{Table 9 Statistics F Test Results}

Based on the test results above, obtained an $F$ count of 18,024 with a significance value of 0,000 . The significance level is smaller than 0.05 , it can be concluded that company size, leverage, price earning ratio (PER), and return on equity (ROE) simultaneously affect the firm value an.

c. Coefficient of Determination

The coefficient of determination (R2) measures how far the model's ability to explain the variation of the dependent variable (Ghozali, 2011). The larger (close to 1), the better the results for the regression model and the closer to 0 , the overall independent variable can not explain the dependent variable (Sulaiman, 2004). Values are small means the ability of these variables in explaining variabe Idependen very limited. A value close to 1 
means that the independent variables provide all the information needed to predict variations in the dependent variable (Ghozali, 2011).

In table 10 it can be seen that the $R$ square value is 0.586 or $58.6 \%$. This shows that variations in firm value that can be explained by firm size variables, Leverage, Price Earning Ratio (PER), and Return On Equity (ROE) of $58.6 \%$. While the remaining $41.4 \%$ is explained by other variables outside the model.

\section{B. Discussion research}

1. Effect of company size on firm value

Based on the t test it can be seen that the value of the company has a regression coefficient with a positive sign of 0.065 with a significance level of 0.299 . The significance results indicate that the level of significance of firm size variables is greater than $\alpha=0.05$, it can be concluded that company size has a positive and not significant effect on firm value so hypothesis $1(\mathrm{H} 1)$ which states that company size has a positive and significant effect on firm value rejected.

Thus it can be concluded that the greater size of the company does not mean that does not necessarily increase the value of the company. The results of this study indicate that investors do not consider the size of the company when they buy shares. the results of this study are not in accordance with research conducted by (Rina, 2016) and (Bhekti, 2013) which states that company size has a positive and significant effect on firm value. Although this research is not in accordance with the proposed hypothesis, this research is in accordance with the results of research conducted by (Hesty, 2013).

2. Effect of Leverage on firm value

Based on the results of the test it can be seen that the leverage proxied by Debt Earning Ratio (DER) has a regression coefficient with a negative sign of 0.62 with a significance level of 0.598 . The significance results indicate that the level of significance of the Leverage variable is greater than $\alpha=0.05$, it can be concluded that Leverage has a negative and not significant effect on firm value so that hypothesis $2(\mathrm{H} 2)$ which states that Leverage has a positive and significant effect on firm value is rejected.

This indicates that if the company increases or decreases its funding sources it will not affect the overall value of the company because in the Indonesian capital market the stock price movement and the creation of the company's added value are influenced by psychological market factors.
The size of the debt owned by the company is not given much attention by investors, because investors look more at how the company's management uses these funds

Table 10 Determination Coefficient Test Results Summary Model ${ }^{\mathbf{b}}$

\begin{tabular}{|c|c|c|c|c|c|}
\hline $\begin{array}{l}\text { Mo } \\
\text { del }\end{array}$ & $\mathrm{R}$ & $\begin{array}{c}\mathrm{R} \\
\text { Square }\end{array}$ & $\begin{array}{l}\text { Adjusted } \\
\text { R Square }\end{array}$ & $\begin{array}{l}\text { Std. } \\
\text { Error } \\
\text { of the } \\
\text { Estima } \\
\text { te }\end{array}$ & $\begin{array}{c}\text { Durbin } \\
- \\
\text { Watso } \\
n\end{array}$ \\
\hline 1 & $765^{a}$ &, 586 &, 553 &, 58235 & 1,970 \\
\hline
\end{tabular}

a. Predictors: (Constant), LNROE, LNPER,

LNLEVERAGE, LNSIZE

b. Dependent Variable: LNTobinsQ

effectively and efficiently to achieve added value to the company's value.

In the results of this study Leverage has a negative and not significant effect on the value of the company. That is, companies in funding their assets tend to use their own capital from retained earnings and share capital rather than using debt. The adequacy of funds owned by the company to finance its assets obtained from its own capital makes the company reduce the proportion of debt. The use of excessive debt will reduce the benefits received from the use of debt because the benefits received are not proportional to the costs incurred, so that a low proportion of debt use can increase the value of the company and conversely an increase in debt can reduce the value of the company. The results of this study are consistent with research conducted by (Bhekti, 2013), and (Faradila n.d 2017) which states that leverage has a negative and not significant effect on firm value.

3. Effect of Price Earning Ratio (PER) on firm value

Based on the $t$ test results in table 4.6 above, it can be seen that Price Earning Ratio (PER) has a regression coefficient with a positive sign of 0.340 with a significance level of 0.004. The significance result shows that the significance level of Price Earning Ratio (PER) is smaller than $\alpha=0.05$, it can be concluded that Price Earning Ratio (PER) has a positive and significant effect on firm value so that hypothesis $3(\mathrm{H} 3)$ states that Price Earning Ratio (PER) has a positive and significant effect on firm value received.

Price Eraning Ratio (PER) is one of the most favorite ratios used, because it is quite easily understood by investors and potential investors. The low value of Price Earning Ratio (PER) informs investors that the company's stock price is cheap or worth buying because it has the potential to rise in the future. A low Price Earning Ratio (PER) means the company's profit is getting higher, 
which means the company's value is in good condition.

For the company, the impact of Price Eraning Ratio (PER) reflects a good indicator to determine future stock returns, where the higher the Price Earning Ratio (PER), the higher the price per share of a company and indicates a good company value.

Investors have different responses to the value of Price Earning Ratio (PER) owned by the company, it all depends on the preferences of each investor. Investors who like to take risks have a tendency to speculate so that they prefer a higher Price Earning Raatio (PER). The higher Price Earning Ratio (PER) indicates that stock prices are increasing and from an increase in the price of these shares has the potential to bring profit on the difference in stock prices.

Investors who tend to avoid risk prefer the low value of Price Earning Ratio (PER) because the low value of Price Earning Ratio (PER) shows the greater the dividends distributed and the faster return of capital on investments made and with the expectation if they buy shares whose price when it is cheap, it will bring a higher stock return if the price rises again. So the Price Earning Ratio (PER) ratio is seen by investors as a measure of the ability to generate future profits from a company. The results of this study are consistent with research conducted by (Bhekti, 2013) which explains that Price Earning Ratio (PER) has a positive and significant effect on firm value .

4. Effect of Return On Equity (ROE) on firm value

Based on the results of the $t$ test it can be seen that the Return On Equity (ROE) has a regression coefficient with a positive sign of 0.506 and a significance level of 0.000 . The significance result shows that the significance level of the Return On Equity (ROE) variable is smaller than $\alpha=0.05$, it can be concluded that Return On Equity (ROE) has a positive and significant effect on the firm's value so that hypothesis $4(\mathrm{H} 4)$ states that Return On Equity (ROE) has a positive and significant effect on the value of the company received.

Return on Equity (ROE) reflects the level of return on investment for shareholders. This ratio can be used by investors to consider in decision making. The higher Return On Equity (ROE) the better the company and the higher the rate of return to shareholders. a high level of Return On Equity will be able to attract investors to invest their capital in the company, thereby increasing the value of the company.

The higher Return On Equity (ROE) which is considered as a measure of the company's profitability will also increase earnings per share of the company. An increase in earnings per share of the company will make investors interested in sinvesting their capital by buying company shares. With so many investors buying company shares, it will raise the price of the company's shares so that it will increase the value of the company. The results of this study are consistent with research conducted by (Tuma, J. M., \& Pratt, J. M. (1982). Clinical child psychology practice and training: A survey. Vdots of Clinical Child \& Adolescent Psychology, 137(August 2012) et al., 2002) (Rosiana \& Triaryati, 2016), (Bhakti, Bakri, \& Hamidah, 2013) and (Rachmat, Nugroho, Sukma, \& Aswidinnoor, 2014) which stated that profitability proxied by Return on Equity (ROE) had a positive and significant effect on firm value.

\section{CONCLUSION}

From the results of partial data analysis, it is obtained that the Company Size variable (SIZE) has a positive and not significant effect on firm value. This can mean that if the size of the company rises, the value of the company also rises but shows insignificant results. Leverage variables that are proxied by Debt Equity Ratio (DER) have a negative and insignificant effect on the firm's value. This can be interpreted that if leverage decreases the value of the company will rise but shows insignificant results. Variable Price Earning Ratio (PER) and variable Return On Equity (ROE) has a positive and significant effect on firm value. This can be interpreted that if Price Earning Ratio (PER) and Return On Equity (ROE) rises, the value of the company also rises and shows significant results.

From the analysis of data simultaneously, the variable size of the company, Leverage, Price Earning Ratio (PER) and Return on Equity (R OE) in this study disimpu The fish that the variable indep Enden collectively the same be rpengaruh to variable dep eden value company. This is based on the calculated $F$ value of 18,024 with a significance level of 0,000 which is much smaller than $\alpha=0.05$.

\section{REFERENCES}

Bhakti, Rizki Tri Anugrah, Bakri, Mochammad, \& Hamidah, Siti. (2013). Pemberdayaan UMKM dan Lembaga Keuangan Syariah melalui Prinsip Bagi Hasil. De Jure: Jurnal Hukum Dan Syar'iah, 5(1).

Ghozali, Imam. (2011). Application of multivariate analysis with SPSS program. Semarang: Diponegoro University Publishing Agency.

Ghozali, Imam, \& Chariri, Anis. (2007). Accounting theory. Semarang: Badan Penerbit Universitas Diponegoro. 
Karnadi, Magdalena. (1993). Pengendalian Persediaan Bahan Baku dalam Pembuatan Plat Baja pada PT Jaya Pari Steel.

Prasetyorini, Bhekti Fitri. (2013). The effect of firm size, leverage, price earning ratio and Profitability on firm value. Jurnal, 183-196.

Rachmat, Agus, Nugroho, Satya, Sukma, Dewi, \& Aswidinnoor, Hajrial. (2014). Overexpression of OsNAC6 transcription factor from Indonesia rice cultivar enhances drought and salt tolerance. Emirates Journal of Food and Agriculture, 519-527.

Rosiana, Desy, \& Triaryati, Nyoman. (2016). Studi Komparatif Kinerja Keuangan pada Bank Konvensional dan Bank Syariah di Indonesia. E-Jurnal Manajemen Universitas Udayana, $5(2)$.

Sartono, Agus. (2002). Manajemen Keuangan; aplikasi dan teori. BPFE: Yogyakarta.

Sartono, Sartono. (2008). IMPROVING STUDENT'S VOCABULARY MASTERY BY USING DIRECT METHOD (DM) AT THE FOURTH YEAR STUDENTS OF SDN 02 JATEN JUWIRING KLATEN IN 2007/2008 ACADEMIC YEAR (A CLASSROOM ACTION RESEARCH). Universitas Muhammadiyah Surakarta.

Soliha, Euis. (2002). Taswan. 2002. Pengaruh Kebijakan Hutang Terhadap Nilai Perusahaan Serta Beberapa Faktor Yang Mempengaruhinya. Jurnal Bisnis Dan Ekonomi, 9(2), 149-163.

Sujoko, Anang, Safitri, R., \& Anindita, Ratya. (2007). Pemanfaatan Multimedia dalam Pembelajaran sebagai Alternatif Optimalisasi Keseimbangan Kerja Otak kiri dan Kanan Guna Meningkatkan Kualitas dan Daya Saing Lulusan. Prosiding Abstrak. Disajikan Dalam Simposium Nasional.

Suryani, Bhekti. (2013). Panduan Yuridis Penyelenggaraan Praktik Kedokteran. Jakarta, Dunia Cerdas.

Tandelilin, Eduardus. (2010). Investment Analysis and Portfolio Management. Yogyakarta: Canisius.

Tuma, J. M., \& Pratt, J. M. (1982). Clinical child psychology practice and training: A survey. Vdots of Clinical Child \& Adolescent Psychology, 137(August 2012), 37-41. http://doi.org/10.1037/a0022390, Gobry, F. (1999). $\{$ T $\}$ his is a title. $\{M\} y$ Journal, $1,120-$ 130., Keshav, S. (2007). How to Read a Paper. Work, 37(3), 83-84. http://doi.org/10.1145/1273445.1273458, et al. (2002). Middlesex University Doctor of Professional Studies. Studies in Higher Education. 
Copyright holder:

Tegar Prasetya, Setyo Riyantob (2020)

First publication right :

Journal of Social Science

This article is licensed under:

(c) (i) (2) 